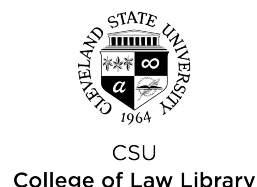

Cleveland State Law Review

Volume 59 | Issue 4

Article

2011

\title{
The Mystery of Life in the Laboratory of Democracy: Personal Autonomy in State Law
}

Adam J. Macleod

Faulkner University, Jones School of Law

Follow this and additional works at: https://engagedscholarship.csuohio.edu/clevstlrev

Part of the Jurisprudence Commons, and the State and Local Government Law Commons How does access to this work benefit you? Let us know!

\section{Recommended Citation}

Adam J. Macleod, The Mystery of Life in the Laboratory of Democracy: Personal Autonomy in State Law, 59 Clev. St. L. Rev. 589 (2011) available at https://engagedscholarship.csuohio.edu/clevstlrev/vol59/iss4/6

This Article is brought to you for free and open access by the Journals at EngagedScholarship@CSU. It has been accepted for inclusion in Cleveland State Law Review by an authorized editor of EngagedScholarship@CSU. For more information, please contact library.es@csuohio.edu. 


\title{
THE MYSTERY OF LIFE IN THE LABORATORY OF DEMOCRACY: PERSONAL AUTONOMY IN STATE LAW
}

\begin{abstract}
ADAM J. MACLEOD*
Recent controversies, such as enactment of an individual mandate to purchase health insurance and the legalization of assisted suicide in Washington and Montana, have renewed the war over personal autonomy. Debates about the value and limits of personal autonomy also play major roles in the controversies over abortion, same-sex intimacy, and same-sex marriage. On one side of the autonomy war, advocates of unfettered individual freedom assert that by her un-coerced and autonomous choice the individual person determines the value of human goods such as life, health, and marriage.

On the other side, proponents of strong government restrictions on personal choice hold that personal autonomy conflicts with personal responsibility. This view is used to support strong government restrictions not only on assisted suicide and marriage, but also on the consumption of drugs, cigarettes, and alcohol; and recently on economic activities, such as the decision on whether to purchase health insurance.

This article attempts to carve a path between the two sides in this autonomy war. It begins by bringing into dialogue with each other four of the most influential legal philosophers of our day: Joseph Raz, Ronald Dworkin, John Finnis, and Robert George. Each of these four scholars makes bold and instructive claims about the value and limits of personal autonomy. The article then examines several different areas of state law where one might expect a principle of autonomy to be implicated, and articulates six important lessons that one can glean from state law about the relationship between personal autonomy and other human goods.
\end{abstract}

I. INTRODUCTION: THE AUTONOMY WAR .............................. 590

II. PERSONAL Autonomy AND BASIC Human GoOdS ............ 593

A. Four Thoughtful Accounts of Autonomy.................... 593

B. A Conversation .......................................................... 594

III. LESSONS FROM STATE LAW ........................................... 598

A. Property Owner Sovereignty .................................. 598

1. The Right to Exclude........................................ 599

2. Owner Sovereignty, Autonomy, and Basic

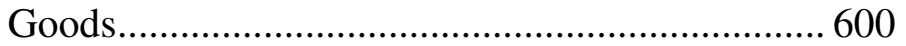

3. In Service to Human Dignity.............................. 605

4. Recent Criticisms of Owner Sovereignty ............ 607

B. Land Use Regulation ............................................ 608

\footnotetext{
* Associate Professor, Faulkner University, Jones School of Law. Thanks to Jorja Loftin for her excellent research assistance and to Hon. Neil Gorsuch, Jeffrey Jones, John Keown, and my colleagues Rob McFarland and Andy Olree for their helpful comments and criticisms. The errors that remain are my own.
} 
C. Charitable Tax Deductions................................................... 611

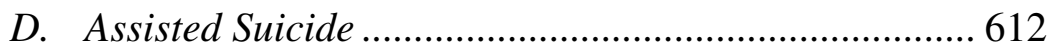

E. Compulsory Education Laws..................................... 617

F. Legalized Marijuana Use ............................................ 620

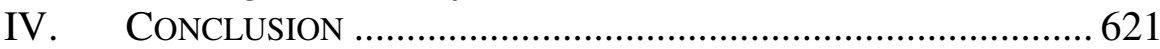

\section{INTRODUCTION: THE AUTONOMY WAR}

Debates about personal autonomy today play major roles in controversial legal and political debates. Arguments in favor of legal rights for assisted suicide, ${ }^{1}$ abortion, ${ }^{2}$ same-sex intimacy ${ }^{3}$ and same-sex marriage, ${ }^{4}$ and for an expansive religious liberty to engage in self-harmful conduct ${ }^{5}$ often share a common presupposition: that by her un-coerced and autonomous choice the individual person determines the value of certain human goods, such as life, health, and marriage. On this account, the law's reach must be curtailed (or, in the case of same-sex marriage supplanting conjugal marriage, a private association should no longer enjoy a privileged place in law) so that the individual can exercise her autonomy in a capacious legal environment. Particularly in matters of religion, morals, and selfharm, where the conduct at issue is perceived not to affect third parties, the principle of personal autonomy is understood to militate in favor of more freedom rather than less. Laws that deflect self-harmful conduct are thought to fail to respect the individual's claim to personal autonomy.

On the other side of the debate many prominent thinkers and lawmakers hold that personal autonomy conflicts with personal responsibility. Give people too much freedom, these folks argue, and they will become irresponsible citizens. Some goods cannot be realized unless citizens are coerced to contribute to the collective good of all.

Thus two conflicting views about the value and limitations of autonomy have arisen. They are easily caricatured because they are both so extreme. On one hand, the belief that personal autonomy militates in favor of ever-expansive liberty is generally expressed with no limitations. This view found its most famous expression in Justice Kennedy's now well-worn claim from Planned Parenthood of Southeastern Pennsylvania v. Casey,

Our law affords constitutional protection to personal decisions relating to marriage, procreation, contraception, family relationships, child rearing, and education ... These matters, involving the most intimate and personal choices a person may make in a lifetime, choices central to personal dignity and autonomy, are central to the liberty protected by the

\footnotetext{
${ }^{1}$ Washington v. Glucksberg, 521 U.S. 702,735 (1997).

2 Planned Parenthood of Se. Pa. v. Casey, 505 U.S. 833 (1992).

${ }^{3}$ Lawrence v. Texas, 539 U.S. 558, 572-74 (2003).

${ }^{4}$ Goodridge v. Dep't of Pub. Health, 798 N.E.2d 941, 948 (Mass. 2003).

5 Emp't Div., Dep't of Human Res. of Or. v. Smith, 494 U.S. 872 (1990). See also ANDY G. Olree, The Choice Principle: The Biblical Case for Legal Toleration 130-47 (2006).
} 
Fourteenth Amendment. At the heart of liberty is the right to define one's own concept of existence, of meaning, of the universe, and of the mystery of human life. Beliefs about these matters could not define the attributes of personhood were they formed under compulsion of the State. ${ }^{6}$

This conception of constitutional protections places personal autonomy on an exalted perch, above the other human goods that Justice Kennedy alluded to. The value of other human goods such as life, marriage, and knowledge is determined by individual choice. These other goods are thus reflexive in nature, meaning that they have intelligible value only if, and to the extent that, they are freely chosen by individual persons.

This article will refer to this caricatured conception as "Untrammeled Autonomy." The Untrammeled Autonomy caricature will be used to refer to Justice Kennedy's mystery-of-life passage from Casey and any principle that takes personal autonomy as a conclusive reason for action as against human goods such as life, marriage, and the other "attributes of personhood."7 Though there is disagreement about the implications of Untrammeled Autonomy, the idea expressed in Casey has found assent among both so-called "conservative"s and so-called "liberal"" judges of both federal ${ }^{10}$ and state ${ }^{11}$ judiciaries.

On the other side of the autonomy battle is a view, also caricatured for purposes of clarity, which perceives little or no value in personal autonomy. According to this view, the government ought to play a strong role in directing citizens to personal responsibility. This view is used to support strong government restrictions not only on assisted suicide and marriage, but also on the consumption of drugs, cigarettes, and alcohol, and recently on economic activities, such as the decision whether to purchase health insurance.

Proponents of this conception of personal autonomy sometimes occupy opposite ends of the political spectrum. At one end, some religious figures can be found calling for the codification of "Judeo-Christian principles" in positive law in order to ensure the moral uprightness of citizens. ${ }^{12}$ At the other end, many of the justifications for the landmark health care legislation that Congress enacted in 2010,

\footnotetext{
${ }^{6}$ Casey, 505 U.S. at 851.

${ }^{7} I d$.

8 See Lawrence, 539 U.S. at 574, for Justice Kennedy's majority opinion.

9 See Compassion in Dying v. Washington, 79 F.3d 790, 813-14 (9th Cir. 1996); Compassion in Dying v. Washington, 850 F. Supp. 1454, 1459-61 (W.D. Wash. 1994).

${ }^{10}$ See, e.g., Quill v. Vacco, 80 F.3d 716, 730 (2d Cir. 1996), rev'd, 521 U.S. 793 (1997).

${ }^{11}$ See, e.g., Goodridge v. Dep't of Pub. Health, 798 N.E.2d 941, 959 (Mass. 2003).

12 D. James Kennedy with Jim Nelson Black, Character \& Destiny, A Nation in SEARCH OF ITS Soul 33, 243 (1994). Kennedy denied that secular government "can invent rules and a system of order without regard for God's perfect law," and claimed, "Morality is the only thing you can legislate!" Id. (emphasis original). Far from threatening freedom, Kennedy believed that his theonomous proposal would promote freedom. Freedom, especially freedom of thought and expression, comes not from recognizing personal autonomy but rather from following Christian principles. Id. at 33.
} 
which includes a mandate that every American purchase health insurance, ${ }^{13}$ rest on the principle that the government should direct citizens to take responsible, moral action to ensure "that everybody should have some basic security when it comes to their health care." ${ }^{14}$ This principle trumps the freedom to choose how to pay for one's health care because Americans have a "shared responsibility" to contribute to health insurance coverage for everyone. ${ }^{15}$

As in the Untrammeled Autonomy camp, there exist wide divergences of views among those who believe that the government should coerce its citizens to exercise personal or collective responsibility. But for simplicity, this article will refer to this caricatured view of autonomy as "Authoritative Paternalism."

The combatants in this conflict often move their debate to the national level and seek to apply their principles to particular, controversial issues in federal law. The stakes are high in controversial disputes, such as the justness of assisted suicide and the definition of marriage. Nationalizing these issues raises the stakes even higher. There remains little room for consensus, much less reasoned understanding, when these issues are nationalized, as when the United States Supreme Court creates a constitutional right to perform a controversial action, ${ }^{16}$ or where Congress and the President forbid an action (such as marijuana use) the immorality of which is a matter of some doubt, and which the states might otherwise permit in some instances. ${ }^{17}$ Gains for one side must be obtained at the expense of the other, and the autonomy war becomes a zero-sum conflict.

This warfare over personal autonomy has at times overlooked two important sources of insight. First, much can be learned about the interaction between personal autonomy and other human goods in state law. State law contains many insights on the relationship between autonomy and other goods and it frequently informs federal courts' interpretation of ambiguous or contested constitutional provisions. In Justice Brandeis's famous word picture, the states are laboratories for policy-making, which conduct "experimentation in things social and economic." 18 Especially when the courts consider claims of fundamental rights, they would be better equipped to address these claims if they understood the contours, forcefulness, and limitations of

${ }^{13}$ Patient Protection and Affordable Care Act, Pub. L. No. 111-148, § 1501 (codified at 42 U.S.C.A. § 18091 (West 2010)).

${ }^{14}$ Remarks by the President and Vice President at Signing of the Health Insurance Reform Bill, White House, OfFice of THE PRESS SEC'y (March 23, 2010), available at http://www.whitehouse.gov/the-press-office/remarks-president-and-vice-president-signinghealth-insurance-reform-bill.

15 Robert Pear, Obama Open to a Mandate on Health Insurance, N.Y. TiMES, June 3, 2009, http://www.nytimes.com/2009/06/04/health/policy/04health.html. This language found its way into the legislation itself. The heading for the provision of the act that contains the individual mandate is titled, "Shared Responsibility for Health Care." OFFICE OF THE LEGIS. Counsel, $111^{\mathrm{TH}}$ Cong., Compilation of Patient Prot. and Affordable Care Act 143 (2010).

16 See, e.g., Roe v. Wade, 410 U.S. 113, 116 (1973).

${ }^{17}$ In Gonzales v. Raich, 545 U.S. 1, 15 (2005), the Supreme Court held that the criminal prohibition in United States federal law against the possession of marijuana preempts more permissive state laws.

${ }^{18}$ New State Ice Co. v. Liebmann, 285 U.S. 262, 311 (1932) (Brandeis, J., dissenting). 
the personal autonomy principle on which they are being asked to rely. Much of this can be gleaned from studying the laws of the states.

Second, none of the landmark cases, and almost none of the scholarly literature, consider the value of autonomy in the context of the basic human goods in favor of which it is exercised. This is a serious deficiency because, as a result, many people view personal autonomy as binary, either implicated or not in any particular issue. But by considering the instrumental value of autonomy in its service of extrinsic ends one realizes that personal autonomy is a multi-faceted good. It is neither absolutely valuable nor entirely lacking in value. Rather, its value is contingent upon the uses to which it is put.

This article will begin in Part II with a brief sketch of the recent work that legal philosophers have done to understand the relationship between personal autonomy and other human goods. Part III will then proceed to examine what state lawmakers have said about the question, and what can be learned from their enactments. This article will only scratch the surface of the insights that state law has to offer about the relationships between personal autonomy and other human goods. The approach here is shallow and broad.

In the end, state law teaches six important lessons about the relationship between personal autonomy and other human goods. These are:

1. Personal autonomy is an important condition of pre-moral choosing among basic human goods.

2. The state properly restricts exercises of personal autonomy that cause harm.

3. Personal autonomy is an important condition of the realization of reflexive basic goods.

4. Some autonomous acts are valueless.

5. Not all basic goods appear to be reflexive.

6. Neither a principle of personal autonomy nor the unconditional value of some basic goods conclusively resolves every controversial issue.

\section{Personal Autonomy and Basic Human Goods}

\section{A. Four Thoughtful Accounts of Autonomy}

Many serious jurisprudential scholars have in recent decades turned their attention to the problem of personal autonomy and the realization of human goods and have helped to carve a path between Untrammeled Autonomy and Authoritative Paternalism. This part will consider four of the most thoughtful accounts of personal autonomy, those of Ronald Dworkin, Joseph Raz, John Finnis, and Robert George. All four affirm the value of personal autonomy. Dworkin considers autonomy an essential element of a life lived well. ${ }^{19}$ Raz considers autonomy a basic human good, having intrinsic value and thus constituting a reason for choice and action in and of itself. ${ }^{20}$ Finnis takes autonomy to be an important precondition to the realization of certain human goods, such as friendship, practical reasonableness, and religious

19 Ronald Dworkin, Life's Dominion: An Argument About Abortion, Euthanasia, AND INDIVIDUAL FREEDOM 84-94 (1994).

${ }^{20}$ Joseph Raz, The Morality of Freedom 7, 390-395 (1986). 
exercise, which can be realized only if they are freely chosen. ${ }^{21}$ And George asserts that the free choice exercised in an autonomous act makes right actions more perfect than they would be if coerced. ${ }^{22}$

All four of these thinkers also recognize important limitations upon the reach and value of personal autonomy. Dworkin recognizes the fundamental conviction that one cannot make a wrong action right simply by choosing it; "a person's thinking a given choice right for him does not make it so." 23 Raz observes that personal autonomy is subject to the contingencies of "appropriate mental abilities, an adequate range of options, and independence." ${ }^{24}$ And Finnis and George, while affirming the important instrumental value of personal autonomy, both deny that autonomy is valuable in and of itself..$^{25}$

The remainder of this part will bring these four thinkers into dialogue with each other. The object will be not to resolve any differences among them but rather to use their points of agreement, and points on which they can be reconciled, to frame the consideration of state laws' treatment of autonomy, which follows.

\section{B. A Conversation}

Raz provides a helpful definition of personal autonomy. The "ruling idea" is "that people should make their own lives" by choice. ${ }^{26}$ Personal autonomy is an "ideal of self-creation." 27 In embracing goals and commitments and remaining true to them one "gives shape to one's life, determines what would count as a successful life and what would be a failure." 28 Dworkin, Finnis, and George agree with Raz that people can, to some extent, create their own reasons for action simply by choosing to do so. As Finnis observes, where one is faced with a choice between two incompatible but equally-reasonable options, it is the act of choosing itself, the exercise of free will, which settles the question. ${ }^{29}$

21 John Finnis, Moral Absolutes: Tradition, Revision, and Truth 20-24 (1991) [hereinafter "FinNIS, MORAL ABSOLUTES"]; John Finnis, Liberalism and Natural Law Theory, 45 MERCER L. REV. 687, 694-95 (1994) [hereinafter "Finnis, Liberalism and Natural Law"].

22 Robert George, Making Men Moral: Civil Liberties and Public Morality 17677 (1993).

${ }^{23}$ DwORKIN, supra note 19, at 206.

${ }^{24}$ RAZ, supra note 20, at 372.

${ }^{25}$ GeOrge, supra note 22, at 175-80; John FinNis, NATURAL LAW AND NATURAL Rights 85-90 (1980) [hereinafter "FINNIS, NATURAL LAW AND NATURAL RIGHTS"]; Finnis, Liberalism and Natural Law, supra note 21, at 691-92.

${ }^{26}$ RAZ, supra note 20, at 369. This is true even for people who deny the value of autonomy. Id. They, like everyone else, are better off living autonomous lives than nonautonomous lives. Id.

27 Id. at 370 .

28 Id. at 387.

${ }^{29}$ Finnis, Moral Absolutes, supra note 21, at 58. The act of choosing rationally "is creative of personal character, and thus of a most significant aspect of the reality of each person who is capable of meaningful relations with other persons." Id. It demonstrates the capacity, so unique to human beings, to establish "some meaningful relationship between his or her feelings, understanding, judgments, and actions." Id. 
For this reason, a person's life consists in part of values and reasons of his own making. But Raz hastens to reject the "exaggerated ... doctrine of arbitrary selfcreation," which holds that all value derives from choice which is itself not guided by value. ${ }^{30}$ Raz insists, "[a]utonomy requires a choice of goods. A choice between good and evil is not enough." ${ }^{31}$ Likewise, Finnis denies that all reasons for action are created by choice; some human goods simply are good, apart from free choice. ${ }^{32}$ And George insists that the "suitability of objects of choice" must be judged "by reference to standards sufficiently impersonal and objective to be counted as reasons." 33 Otherwise, actions cannot be chosen for reasons, but only for desires, appetites, and other sub-rational preferences. Thus these thinkers substantially agree that personal autonomy is not the most fundamental value. Respect for personal autonomy entails respect for other equally-fundamental human goods, such as life, health, and marriage, as well.

To see why this is so, it is important to consider how personal autonomy is actually exercised. Raz explains that the achievement of autonomy requires not merely freedom from coercion but also a range of acceptable options from which to choose. $^{34}$ "One cannot have an option to be a barrister, a surgeon, or a psychiatrist in a society where those professions, and the institutions their existence presupposes, do not exist." ${ }^{35}$ Because humans are essentially social creatures, and share common views about which options are worthwhile, many common goods are, in fact, both common and intrinsically good. ${ }^{36}$ Finnis explains that the commonality of goods does not entail "that the members of a community must all have the same values or objectives." 37 But there must be "some set (or set of sets) of conditions which needs to obtain if each of the members is to obtain his own objectives." ${ }^{\prime 3}$

In other words, the achievement of personal autonomy entails that the individual is not free to determine the value of all goods. In order to make one's own reasons and projects through the exercise of personal autonomy one must respect preexisting, objective reasons not of one's own making. Some find this insight counterintuitive. But careful consideration reveals considerable merit in it.

So to have acceptable options one must discover other objective goods, which are at least equally as valuable as autonomy, which one shares in common with other

${ }^{30}$ RAZ, supra note 20 , at 387-88.

31 Id. at 379.

${ }^{32}$ See discussion infra.

33 George, supra note 22, at 154.

${ }^{34}$ RAZ, supra note 20, at 148-57. Raz distinguishes between the capacity to achieve autonomy and the achievement of autonomy. Id. Autonomy as a capacity requires freedom from coercion. Autonomy as achievement requires more. Id. at 203-05. The ideal of autonomy cannot be achieved without "having a sufficient range of acceptable options." Id. at 205.

${ }^{35} I d$.

${ }^{36} I d$.

37 FinNis, NATURAl LaW AND NATURAL Rights, supra note 25, at 156.

${ }^{38} I d$. 
people, and which provide reasons to choose them. ${ }^{39}$ Finnis has helpfully identified these other goods. They are life (including health), knowledge, play, aesthetic experience, friendship, practical reasonableness (what some call reasonable action or morally-upright choosing), and order with ultimate reality (what Finnis "summarily and lamely," in his words, called "religion"). ${ }^{40}$ From these basic goods all other human goods derive their value.

These basic goods are common in several senses. They are good for all and known to all. ${ }^{41}$ That people disagree about what is good does not entail that all goods are subjective; knowledge, for example, simply is better than ignorance. ${ }^{42}$

Also, realization of the goods is neither an individual project (as Untrammeled Autonomy proponents would have it) nor a matter of the collective good of the greatest number (as many Authoritative Paternalists would portray the matter). Rather, one participates in goods with others in projects of cooperation and common commitment. ${ }^{43}$ Thus, the "common good" is not collective in the utilitarian sense of the greatest aggregate good for the greatest number, ${ }^{44}$ which necessarily contradicts or overrides the goods (and autonomy) of individuals. Rather, the "common good"

${ }^{39}$ RAZ, supra note 20, at 205-06.

40 Finnis, NAtUral Law AND NATURAl Rights, supra note 25, at 85-90. In a later writing, Finnis provided a slightly modified list, identifying the basic goods as (1) knowledge; (2) skillful performance in work and play; (3) bodily life and the components of its fullness, such as health and safety; (4) friendship and association between persons; (5) conjugal marriage; (6) practical reasonableness; and (7) "harmony with the widest reaches and most ultimate source of all reality, including meaning and value." Finnis, Liberalism and Natural Law, supra note 21, at 691-92. The point here is not to nail down a precise and comprehensive list but rather to observe that there are basic goods, that they are at least equally as basic as personal autonomy.

${ }^{41}$ Finnis observes that all human societies show concern for these goods, or some forms or instantiations of these goods, and the practical principles that guide their realization. FINNIS, NAtURAl LAW AND Natural Rights, supra note 25, at 83-84. Though no value is recognized at all times, in all places, in the same way, anthropologists find with "striking unanimity" that the basic goods are known to all societies in some way. Id. at 83. The basic goods are "good for any and every person." Id. at 155.

${ }^{42}$ Finnis observes that, in moving from an inclination toward knowledge to a grasp of its self-evident value, "[o]ne finds oneself reflecting that ignorance and muddle are to be avoided, simply as such and not merely in relation to a closed list of questions that one has raised." Id. at 61. One recognizes that a "well-informed and clear-headed person" is well-off, not merely because he can make instrumental use of his knowledge, and profit from it, but it is good for everyone to know. Id. And this holds not merely for oneself and one's own interests, "but at large." Id.

${ }^{43}$ To illustrate, Finnis holds up the basic good of friendship: "For A to be B's friend, A must act (at least in substantial part) for the sake of B's well-being, and must value B's wellbeing for the sake of B. A must treat B's well-being as an aspect of his (A's) own wellbeing." Id. at 142-43. But the same is also true of B: "It follows that A must value his (A's) own well-being for the sake of B, while B must value his (B's) own well-being for the sake of A. And so on. The reciprocity of love does not come to rest at either pole." Id. at 143.

${ }^{44} \mathrm{Id}$. at 154 . Because the basic goods are incommensurable, this consequentialist calculation is unworkable, incoherent, and irrational. Id. at 111-18; RAZ, supra note 20, at 321-66. 
refers to "the factor or set of factors ... which, as considerations in someone's practical reasoning, would make sense of or give reason for his collaboration with others and would likewise, from their point of view, give reason for their collaboration with each other and with him." 45

But nor is the common good realized merely through individual choice. Indeed, personal autonomy itself cannot be reconciled with moral individualism. As Raz observed, the associations and institutions that form around joint participations in the good are essential predicates of the exercise of personal autonomy because they make available a range of adequate options in which individuals might choose to participate. ${ }^{46}$ For this reason, Raz recognized that moral individualism is incompatible with personal autonomy. ${ }^{47}$

All of this causes Ronald Dworkin to feel a tension in moral reasoning. On one hand, one's commitment to a particular conception of the good is part of what makes that commitment valuable for that individual person. ${ }^{48}$ On the other hand is the "even more fundamental conviction" that some conceptions of the good are mistaken, "that a person's thinking a given choice right for him does not make it so." ${ }^{49}$ Moral reasoning is thus a process of both choice and judgment. ${ }^{50}$ This tension between choice and judgment poses for Dworkin a dichotomy. The significant value of autonomous choice, and the integrity it safeguards, pulls Dworkin toward "the annihilating idea that critical interests are only subjective, only matters of how we feel." 51 The belief that some choices are wrong pulls him toward the "equally unacceptable idea that everyone's critical interests are the same, over all history, that there is only one truly best way for anyone to live." 52

Raz and George see a way out of this conundrum. One can affirm the basic, unconditional value of some human goods without insisting on only one truly best way to live. Raz and George both recognize "many forms of the good which are admitted to be so many valuable expressions of people's nature," while also affirming "that certain conceptions of the good are worthless and demeaning, and that political action may and should be taken to eradicate or at least curtail them.",53

\footnotetext{
${ }^{45}$ FinNis, NATURAl LAW AND NATURAL Rights, supra note 25, at 154.

46 RAZ, supra note 20, at 206.

${ }^{47} \mathrm{Id}$.

${ }^{48}$ DwORKIN, supra note 19, at 206.

${ }^{49} I d$.

${ }^{50} I d$.

${ }^{51} I d$.

${ }^{52} I d$.

${ }^{53}$ GeORGE, supra note 22, at 164 n.7 (quoting RAZ, supra note 20, at 133).
}

To see why this is so, take a couple of easy cases. A person might choose not to get married in order to pursue a life of religious instruction and charitable work. This person has reasonably chosen to pursue the human goods of religious exercise and charity over the human good of marriage. But this choice does not entail denigrating the value of marriage, or insisting that celibacy is the only way to live. It merely reflects the reality that one must choose between mutually-inconsistent ends. Similarly, one who chooses to 
For this reason, personal autonomy and the other human goods need not conflict with each other. The question is not, as proponents of Untrammeled Autonomy would have it, whether the state should leave people free to make autonomous choices. Nor is the question, as proponents of Authoritative Paternalism would pose it, how much freedom citizens should have to act irresponsibly. Rather, the question for lawmakers is which autonomous choices realize real human goods, and therefore ought to be left as matters of personal choice, and which harm the good, and can rightly be disincentivized or even prohibited. That question is not an easy question to answer. But the judgments of state lawmakers on that question reveal some helpful insights.

\section{LESSONS FROM STATE LAW}

Because state lawmakers frequently must make judgments about which ends are worth realizing through coercive means, it is possible to inquire more closely about the value and limits of autonomy by looking at state law. This article now turns to examine a few, discrete areas of state law where autonomy plays a role, or is thought to play a role, in determining which of two (or more) policies the state should pursue.

Admittedly, state lawmakers are not always, or perhaps even often, clear about what value they attribute to personal autonomy and other goods. But their deliberations and decisions reflect definite commitments on this subject. Those commitments are entitled to examination not because they are necessarily correct but because they provide useful starting points from which to explore the extent of respect state law can and should afford to personal autonomy. Examining state law with a critical eye reveals some helpful lessons about the value of autonomy because the judgments of state lawmakers have real-world consequences, and these can be studied.

Thus, the goal here is not to derive normative judgments from what state law currently is or from what state lawmakers have done. Indeed, some state laws are bad laws precisely because they are predicated on wrong views about autonomy. Rather, the goal is to determine what sort of reason for action autonomy turns out to be after it has been tested in the laboratory of democracy.

\section{A. Property Owner Sovereignty}

Lesson One: Personal Autonomy Is an Important Condition of Pre-Moral Choosing Among Human Goods

pursue a career in music over a career in scientific research has not judged the good of aesthetic experience to be objectively superior to the human good of knowledge, or that a career in music is the only sensible career for everyone.

At the same time, some choices are simply worthless, and therefore unreasonable. The deliberate destruction of a basic good, such as life, has no intelligible value. Murder is therefore wrong, and is a fundamentally different choice than the decision not to conceive a child in the first instance. Similarly, to choose a career in music over a career in scientific inquiry is not the same as obscuring scientific knowledge by, for example, falsifying the data from one's research. Destroying a basic good is not the same as not choosing to instantiate it in the first place. 
The control and freedom that make personal autonomy possible are on vivid display in the sovereignty that a property owner exercises over his assets. State law accords striking respect to the owner of private property, and strongly protects the rights that enable him to control his asset, particularly his right to exclude others from it. Civil and criminal trespass laws carve out, for the property owner, a space of dominion, within which he is free to use his asset for his own personal ends within the limitations discussed in the next part.

\section{The Right to Exclude}

The right to exclude has clear boundaries and sharp edges. Thus, the "midnight streaker who dashes unseen across the lawn of another, and who merely bends a few blades of grass in the process, is guilty of the tort of trespass." ${ }^{.54}$ One trespass case in particular reveals the impregnability of property owner sovereignty. In Jacque v. Steenberg Homes, Inc., ${ }^{55}$ the Wisconsin Supreme Court upheld a $\$ 100,000$ punitive damages award for a trespass that resulted in no actual damages. The Jacques forbad Steenberg Homes, a mobile home sale company, to cut a path across their frozen, snow-covered field to a neighbor's tract. ${ }^{56}$ The only alternative course contained a sharp curve, was covered in seven feet of snow, and would require extra equipment to navigate. ${ }^{57}$ Because delivery was included in the sale price of the mobile home ${ }^{58}$ Steenberg Homes had a strong financial incentive to use the easier route over the Jacques's land. But the Jacques wrongly believed that permitting Steenberg Homes to make the delivery over their land would give rise to an adverse possession claim against them ${ }^{59}$ and they remained steadfast in their refusal, despite repeated requests. ${ }^{60}$

Steenberg Homes delivered the mobile home over the Jacques's property without permission. ${ }^{61}$ In the ensuing trespass action a jury awarded the Jacques $\$ 1$ in nominal damages and $\$ 100,000$ in punitive damages. ${ }^{62}$ In upholding the award, the Wisconsin Supreme Court affirmed the individual property owner's "strong interest in excluding trespassers." ${ }^{63}$ But the court went further and asserted that "[s]ociety has an interest in punishing and deterring intentional trespassers beyond that of protecting the interests of the individual landowner." ${ }^{64}$ This drastic remedy was

54 Thomas W. Merrill \& Henry E. Smith, The Morality of Property, 48 WM. \& MARY L. REV. 1849, 1871 (2007).

55 Jacque v. Steenberg Homes, Inc., 563 N.W.2d 154 (Wis. 1997).

${ }^{56} I d$. at 157.

${ }^{57} \mathrm{Id}$.

${ }^{58} I d$. at 156.

59 Id. at 157.

${ }^{60} \mathrm{Id}$.

${ }^{61} I d$.

${ }^{62} \mathrm{Id}$. at 158 .

${ }^{63}$ Id. at 160.

${ }^{64} \mathrm{Id}$. 
necessary to preserve the "integrity of the legal system"65 and to vindicate the public expectation that wrongdoers should be "appropriately punished."

Commenting on this decision, Thomas Merrill and Henry Smith have noted the strikingly moral tone of the court's reasoning. The court treated the Jacques's right to exclude as a moral right, and allowed punitive damages to vindicate this right, "not to promote public utility by preventing violence or protecting privacy." other words, this is not a case about the collective good of the greatest number. Rather, the case illustrates the "moral side of property law." 68

\section{Owner Sovereignty, Autonomy, and Basic Goods}

Why does state law provide such rigorous protection to the owner-sovereign? And why would a state high court use such strong moral language in defense of this protection? A clue can be found in the purposes for which property owners exercise their property rights. The point of private property is to serve human goods, such as life, health, personal autonomy, and practical reasonableness, the very goods that Finnis identified as those necessary for the exercise of personal autonomy. ${ }^{69}$ A person who exercises sovereignty over her assets does not always realize these goods, but has the resources necessary to do so. And whatever other values it may serve in particular cases, sovereignty over one's property entails free choice, an essential precondition to both autonomy and practical reasonableness. ${ }^{70}$ Thus property serves both personal autonomy and other human goods.

${ }^{65} \mathrm{Id}$.

66 Id. at 161 .

${ }^{67}$ Merrill \& Smith, supra note 54, at 1873.

${ }^{68} I d$. at $1870,1874$.

${ }^{69}$ See FinNis, NATURAl LAW AND NATURAL RIGHTS, supra note 25, at 165-73.

70 See GEORGE, supra note 22 , at $168,177-78$. One can affirm this role for autonomy whether one takes autonomy to be a basic good or merely an instrumental good. Raz and Finnis both understand autonomous choice to operate in this way. Both affirm that a choice between basic goods is a choice between incommensurables, and is thus undetermined by reason, and that the act of choosing itself both settles the underdetermined question and creates a new reason for action. RAZ, supra note 20, at 388-89; FINNIS, MORAL ABSOLUTES, supra note 21 , at 58 . 
Property owners choose to purchase, use, encumber ${ }^{71}$ and alienate their property rights $\left(\right.$ or not $^{72}$ ) in order to realize certain ends, such as a more aesthetically-pleasing kitchen, an extra bedroom to accommodate new additions to the family, or the investment value of home ownership. The value of these ends is generally derived from more basic goods, such as beauty, health, and life. For example, the addition of an extra bedroom can be instrumentally valuable for its enabling the more fundamental end, the addition of a new child to the family, which is an instance of the basic human good of life.

Property owner sovereignty is therefore consistent with George's account of autonomy as instrumentally valuable. The autonomy carved out within the sovereign owner's property interest enables the owner to realize human goods other than autonomy, and to make pre-moral choices among mutually-exclusive possibilities. But owner sovereignty is also consistent with Raz's concept of autonomy-as-achievement. Just as the achievement of autonomy requires the availability of acceptable options, it requires the availability of sufficient resources to attain those options.

${ }^{71}$ It is important to note that the freedom to use one's property in order to incur an obligation serves, rather than limits, personal autonomy. Property owners, like all persons, create moral reasons when they choose to oblige themselves. Binding obligation is itself a reason for action, in part because people choose to accept obligations for intelligible reasons. A lessor, for example, promises to honor and to protect the lessee's quiet use and enjoyment in order to gain something that he could not have obtained otherwise. Or consider the decision to incur a mortgage obligation in order to purchase a home. When one chooses to own (rather than rent) one's home, one accepts the obligations associated with the loan as the end product of deliberative choice about one's personal priorities and commitments in light of certain, fixed facts.

Just as particular obligations follow from autonomous reflection on the good ends one has chosen to pursue, obligation generally is the conclusion at the end of a chain of inferences derived from the common good. See Finnis, NAtural LaW AND NAtURAL Rights, supra note 25 , at 302 . Obligation is a means of cooperation, which enhances both collective productivity and individual autonomy. Id. at 303.

Like the law, [the institution of obligation] enables past, present, and predictable future to be related in a stable though developing order; enables this order to be effected in complex interpersonal patterns; and brings all this within reach of individual initiative and arrangement, thus enhancing individual autonomy in the very process of increasing individuals' obligations.

Id. Indeed, the point of the institution of binding obligation is to enable individuals to exercise control over their relationships within a community. $I d$. at 308.

${ }^{72}$ Owner sovereignty must protect both the right of the owner to take action and the right not to take action. Even the non-use of an asset can promote the good, as where a farmer allows his fields to lie fallow for a year so that they can recover. The replenished fields produce higher yields in subsequent years, serving the goods of life and health. The point of this central aspect of property is to give the owner freedom to choose. And this freedom to choose enables the owner to realize real human goods.

It bears repeating here that, if Raz, Finnis, and George are correct, these goods are common. So, for example, a community celebrates the birth of a new human because that child's life will accrue to the good of all with whom she is in community. And the crops produced by the sabbatical farmer are a form of wealth that benefits both the farmer and those who purchase and consume the crops. 
Benjamin Barros, in exploring what he calls the "institutional relationship" between property and freedom, observes that property gives people access to the resources that they need in order to be free. ${ }^{73}$ By carving out a zone where the state or community must justify interference with the owner's sovereignty, property promotes the "ability of individuals to make basic life choices for themselves." But it also does more than this. Freedom would be "an empty concept if a person does not have the resources to act (or refrain from acting) consistent with that freedom.." ${ }^{75}$ Property enables access to those resources, and frees property owners from being "beholden to others." 76

Indeed, the freedom that owner sovereignty enables can be understood to promote autonomy, just as it promotes the other goods that the property owner chooses. Free choices among possible instantiations of basic goods are pre-moral, meaning that they do not implicate moral principles or rules. They are, in the language of moral philosophy, rationally undetermined. One can just as reasonably choose to devote one's assets and resources to being more hospitable as to producing crops. The choice to be a farmer instead of a host, or a host instead of a farmer, is therefore autonomously made. It is the act of choosing, in itself, that creates new reasons for one's future choosing. In the realm of pre-moral choosing among possible instantiations of the good one really does make one's own life.

Assets enable people to make their own lives by creating new reasons for their future actions. People deliberate about how to use their assets because there are almost always countervailing options and considerations. Choosing one end often entails foregoing the pursuit of alternatives, so the pre-moral good chosen must be chosen over other, alternative ends. A pre-moral choice between basic goods is a choice between incommensurables, and is thus undetermined by reason. ${ }^{77}$ And even when the choice is between instrumental goods, which sometimes can be measured against each other such that the choice is not fully undetermined, there generally remains more than one reasonable option. Moral principles will not often resolve the choice. Moral side constraints seldom govern the questions whether a person should

73 D. Benjamin Barros, Property and Freedom, 4 NYU J. L. \& LIBERTY 36, $51-57$ (2009).

${ }^{74} I d$. at 47 . Barros does not explore the implications of his theory for communal property owners, such as civic organizations, religious assemblies, corporations, and charitable groups. But owner sovereignty would seem to promote the freedom and autonomy of groups just as it promotes the freedom and autonomy of individuals. The local Rotary Club, for example, would cease to be distinctive as a particular type of social organization, and to determine its own projects, if it were not free to exclude non-members from the facilities where it assembles.

${ }^{75}$ Id. at 51 .

${ }^{76} I d$. Barros observes that any non-private (he uses the common term "communal") system of property must use some method of resource allocation, which deprives individuals of the freedom "to make decisions of their own on how to pursue their needs and desires." Id. at 52. And the one charged with allocating resources could use distribution as means of rewarding allies and punishing critics, thus depriving people of political freedom. Id. Granting equal rights to resources would not solve this problem. "For example, if person A values housing more than education, and person $\mathrm{B}$ values education more than housing, then equal allocations prevent both A and B from making resource choices needed to enable them to choose for themselves how to live their lives." Id. at 53.

77 RAZ, supra note 20, at 388-89; FinNIS, MorAl ABSOLUTES, supra note 21, at 58. 
rent or own a home, or remodel a kitchen or make do with the old one. Rather, the person enjoys a great deal of freedom to choose.

Where in such cases the choice between incompatible options is not settled by the superiority of one option over the other, or by physical, psychological, or economic limitations, or by legal or moral restrictions, it is the act of choosing itself, the exercise of free will, autonomously exercised, which settles the question. ${ }^{78}$ The person making the choice is in an important sense the maker or creator of the state of affairs that follows the choice: the education of the child; the new, more hospitable kitchen.

Property promotes pluralism. Indeed, property is the paradigmatic pluralist institution. Just as one person's notion of the good life differs from his neighbor's, one person's use of his assets to pursue the good life differs from his neighbor's. But in order to work effectively, property owner sovereignty must free the property owner to pursue projects that others do not value. It must honor and protect the freedom of the owner sovereign to choose between, for example, producing more food and hosting more guests.

This is why both purely economic theories of property and theories of state governance of property are incomplete. Property serves more than merely economic values, and thus secures the right of the owner sovereign to pursue non-economic ends, even when that pursuit is not in her economic best interest. It also enables property owners to pursue goals that the state does not value.

The basic goods are all truly basic and thus incommensurable; they are all equally fundamental reasons for action and cannot be compared with each other. Because the basic goods are incommensurable, and thus cannot be rationally measured on any single criteria, it is the property owner's choice that determines which goods will predominate over others. Sometimes this choice will not make sense to an economist, or to a neighbor who sees property only in economic terms. And the choice will often look odd to government bureaucrats.

So, in a famous case the Connecticut Supreme Court vindicated the right of Helen Vealencis, a co-tenant in a tenancy in common, to force a partition of the tenancy in kind and to prevent a partition by sale. ${ }^{79}$ The court faulted the trial court, which had ordered a partition by sale, for, inter alia, looking only to economic considerations. ${ }^{80}$ The trial court "failed to give due consideration" to Ms. Vealencis' actual and exclusive possession of part of the land, and to the facts that she had made her home there and derived her livelihood from her operation of a family business there. ${ }^{81}$ The state high court set the judgment aside and ordered a remand so that the trial court could consider all of Vealencis' reasons for wanting to stay on the property. ${ }^{82}$

\footnotetext{
${ }^{78}$ FinNis, Moral ABSOLUTES, supra note 21, at 58.

79 Delfino v. Vealencis, 436 A.2d 27, 33 (Conn. 1980).

${ }^{80} \mathrm{Id}$.

${ }^{81} I d$.

${ }^{82} \mathrm{Id}$.
} 
On remand the trial court permitted Ms. Vealencis to remain on the property and honored Vealencis' request for a partition in kind. ${ }^{83}$ Her decision caused her to suffer a significant financial loss. Her two co-tenants developed and sold their allotment for $\$ 725,000$; the partitioned tract that Vealencis retained was worth only $\$ 72,000 .^{84}$ It was in the best financial interest of the parties to sell the entire property for residential development and divide up the proceeds. But the value that Vealencis placed in the land could not be measured in money, and the law honors that value.

Other doctrines also secure the right of the owner sovereign to choose for noneconomic reasons. For example, the doctrine of ameliorative waste authorizes the owner of a future interest in property to prevent the possessory estate holder from improving the asset and increasing its economic value without the future interest holder's consent where the improvement would permanently injure the sentimental or aesthetic value of the asset. In a paradigmatic case, George Brokaw held a life tenancy in a mansion at the corner of 79th Street and Fifth Avenue in New York City. ${ }^{85}$ Operating and maintaining the mansion cost many thousands of dollars annually, and there was no rental market for the residence, so to preserve the mansion entailed significant financial loss. ${ }^{86}$ Brokaw proposed replacing the mansion with an apartment building. ${ }^{87}$ There existed significant demand for apartments, and the proposed building would, he estimated, net a $\$ 30,000$ profit. $^{88}$

Nevertheless, the court sided with the future interest holders, who objected to the proposed demolition of the mansion. The act of changing the estate would be a waste, even if it resulted in economic improvement. ${ }^{89}$ The court explained,

The receipt by [the remaindermen] at the end of the life estate of a 13story $\$ 900,000$ apartment house might be more beneficial to them. Financially, the objecting adults may be unwise in not consenting to the proposed change. They may be selfish and unmindful that in the normal course of time and events they probably will not receive the fee. With motives and purposes the court is not concerned. ${ }^{90}$

These and other doctrines must genuinely baffle anyone who attempts to understand property using a single scale of values. Indeed, any attempt to impose any single value system, whether economic or otherwise, upon property owners must result in hopeless confusion about property law. But property law makes a lot of sense if the institution of property is viewed as a pluralist institution, one that honors and protects the rights of owner sovereigns to pursue incommensurable values in the exercise of their personal autonomy. The law leaves property owners free to make

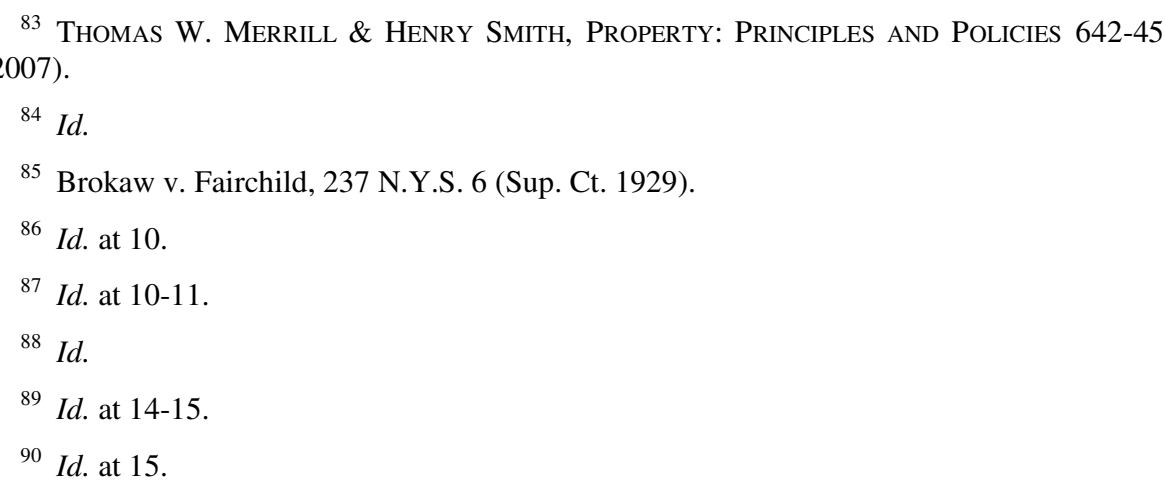


their own determinations about what they value and how they will use property in pursuit of their own values. And this is true even if the choices of property owners seem odd or unwise to an outside observer.

\section{In Service to Human Dignity}

Why should we care whether property owners have the freedom to choose to use their assets to make new reasons for themselves? Freedom to choose for intelligible reasons, and thus to bring a new reality into being, is an essential component of human dignity; it is a central capacity that sets human beings apart from other beings. Finnis has observed that the act of choosing rationally "is creative of personal character, and thus of a most significant aspect of the reality of each person who is capable of meaningful relations with other persons." ${ }^{.11}$ It demonstrates the capacity to establish "some meaningful relationship between his or her feelings, understanding, judgments, and actions." 92 Property owner sovereignty enables the exercise of this capacity. ${ }^{93}$

Because choices about how to use property are generally pre-moral they epitomize the exercise of free choice in its highest and best form. One might encumber one's house with a second mortgage in order to remodel one's kitchen and host more dinner parties. Or one might assume the same mortgage obligation in order to further one's education. One can just as reasonably choose to devote one's assets to being more hospitable as to acquiring knowledge. Given finite value in the house one cannot choose both. But neither is per se unreasonable or immoral. In such cases, which comprise the overwhelming majority of choices about property use, it is the act of choosing that creates a new state of affairs.

By using property to choose between equally-reasonable options, a property owner in an important sense makes her own life. She exercises free choice to bring about a new state of affairs. This is distinctly human achievement. The practice of choosing freely for intelligible reasons, and by choice bringing a new reality and new reasons into being, is an essential component of human dignity. Strong property protection secures the freedom to exercise free choice.

A helpful lesson about the importance of property owner sovereignty to free choice and human dignity is found in the abolition of common law coverture. ${ }^{94}$ That

91 FinNis, MORAl ABSOlutes, supra note 21, at 58.

${ }^{92} \mathrm{Id}$.

93 The view of property that I am sketching here should not be confused with Margaret Jane Radin's famous concept of property that is bound up with the holder. See Margaret Jane Radin, Property and Personhood, 34 STAN. L. REV. 957 (1982). For a more sophisticated account of Radin's theory, see Jeffrey D. Jones, Property and Personhood Revisited, 1 WAKE FOREST J. L. \& POL'Y (2011). The concept of personhood defended here is at odds with Radin's (and Jones'), as is more plain in Part III.D, infra.

94 At English and early American common law a woman's property rights and interests were merged into those of her husband at her marriage under the doctrine of coverture. 1 William Blackstone, Commentaries *442-45; 2 James Kent, Commentaries on AMERICAN LAW 109 (New York, O. Halsted 1827). A married woman, a "feme covert" as she was called, could not own property in her individual capacity in any meaningful sense. Though property law technically permitted her to hold title to assets, she could not exercise any of the powers of ownership. Jesse Dukeminier et AL., Property 312 (6th ed. 2006). For the purposes of property law, the married woman's identity was subsumed within the 
the common law doctrine of coverture denied to married women the opportunity to manage their own assets is the reason why that doctrine was unjust. It was not merely a question of coverture treating men and women differently but also a matter of denigrating the character and personal autonomy, and thus the dignity, of married women.

Around the time of the Married Women's Property Acts, ${ }^{95}$ the Texas Supreme Court observed that coverture deemed the married woman, as a result of her marriage, "divested of her faculties as a rational being." 96 Coverture extinguished the married woman's separate existence on the ground that "her reason, faculties, and intelligence are entombed." ${ }^{.97}$ By this process of entombment, the woman's dignity before the law diminished "to her own detriment and the injury of others," 98 who could not hold her responsible. Meanwhile, her husband enjoyed the corresponding increase in dignity and sovereignty over their joint affairs. ${ }^{99}$

When the states abolished coverture, the married woman's "capacities, reason, and moral being were likewise resuscitated." 100 By freeing the married woman to exercise sovereignty over her assets, the law treated her as a fully reasonable and responsible moral agent, capable of exercising the "right of disposition, control, and management."101 She obtained "distinct and independent rights," which she had the separate responsibility to prosecute and defend in courts of justice. ${ }^{102}$ She was free to choose, and she was expected to accept the consequences of her choices, for good or ill; the law now respected her "faculties and powers as a moral agent" in relation to her property. ${ }^{103}$

As the Texas court recognized, owner sovereignty serves the achievement of honoring one's commitments to oneself and to others. It enables the owner sovereign through the exercise of personal autonomy to make pre-moral choices, which then become binding reasons for her. In short, it empowers her to exercise her faculties of human agency, her reason. And because property respects her choices as rational, it respects her as a person.

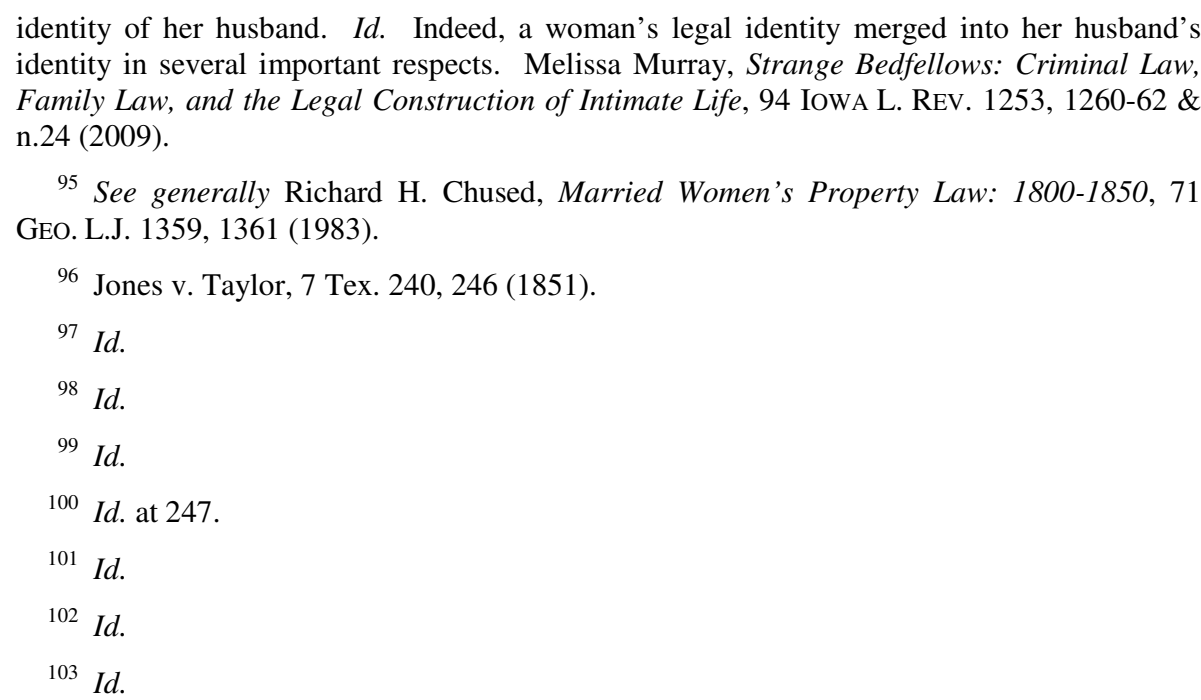




\section{Recent Criticisms of Owner Sovereignty}

A group of influential scholars has recently called into question the prudence and justness of owner sovereignty. These scholars would, inter alia, redistribute property entitlements in favor of collective decision-makers and the poor on the basis of various moral principles, including a "social-obligation norm." 104 They doubt that landowners are likely to use their land more wisely than state actors, and they generally favor a stronger role for law, and a weaker role for sovereign owners, in the use and disposition of property. ${ }^{105}$

Their "Statement of Progressive Property"106 has ignited a controversy over the autonomy that property owners currently enjoy, which is to use and dispose of their own assets. ${ }^{107}$ A full discussion of that controversy is beyond the scope of this article. But two observations are in order. First, it is instructive to note that the parties on both sides of the controversy largely agree that the purpose of property is to serve basic, incommensurable goods, and that whoever has the authority to govern property ought to exercise that authority to promote those goods. ${ }^{108}$ Being in favor of virtue and human flourishing does not entail being opposed to strong private property protections.

Second, there is a real controversy. It is not at all clear that the authors of the Progressive Statement have successfully cast doubt upon the wisdom of owner sovereignty. Their position is consistent with Authoritative Paternalism, which cannot tolerate the strong protections that state property law affords to the owner sovereign. But it is far from clear that property owners are in general incapable of exercising their sovereignty for good.

Indeed, Henry Smith criticizes the Progressive Statement authors for their insufficient attention to the means by which their proposal is supposed to serve the basic goods on which everyone agrees. The problem in Smith's view is not that private property fails to promote human flourishing (it does not fail) but rather that the critics of owner sovereignty are impatient with the "mysterious way" in which property serves human goods. ${ }^{109}$ That everyone favors human flourishing (and its

${ }^{104}$ Gregory S. Alexander, The Social-Obligation Norm in American Property Law, 94 CoRnell L. ReV. 745 (2009).

105 Eduardo M. Peňalver, Land Virtues, 94 CORNELL L. REV. 821 (2009).

106 Gregory S. Alexander, Eduardo M. Peňalver, Joseph William Singer \& Laura S. Underkuffler, A Statement of Progressive Property, 94 CORNELl L. REV. 743 (2009).

107 See, e.g., Alexander, supra note 104; Gregory S. Alexander, The Complex Core of Property, 94 Connell L. Rev. 1063 (2009); Eric R. Claeys, Virtue and Rights in American Property Law, 94 CoRnell L. Rev. 889 (2009); Peňalver, supra note 105; Jedediah Purdy, A Few Questions About the Social-Obligation Norm, 94 CoRnell L. Rev. 949 (2009); Joseph William Singer, Democratic Estates: Property Law in a Free and Democratic Society, 94 CoRnell L. Rev. 1009 (2009); Henry E. Smith, Mind the Gap: The Indirect Relation Between Ends and Means in American Property Law, 94 CoRnell L. Rev. 959 (2009); Katrina M. Wyman, Should Property Scholars Drop Economics For Virtue? A Skeptical Comment, 94 CORNELl L. REV. 991 (2009).

108 Alexander et al., supra note 106, at 743-44; Peňalver, supra note 105, at 864-86; Smith, supra note 107, at 959-63.

109 Smith, supra note 107 at 959. 
constituent goods) does not entail that redistribution of property entitlements is the best means to achieve it, a case that the authors of the Progressive Statement must make for their argument to succeed, but have not made. ${ }^{110}$

\section{B. Land Use Regulation}

\section{Lesson Two: The State Properly Restricts Exercises of Personal Autonomy That} Cause Harm

States do not permit property owners to exercise unfettered autonomy in the use and disposition of their assets. As property professors hasten to point out, the maxim sic utere tuo ut alienum non laedas ${ }^{111}$ does not by itself resolve very many property disputes, but it is a guiding principle in property law. If it means anything, it must mean that owner sovereignty does not entitle a property owner to destroy common human goods. So, for example, the famous case of Katko v. Briney ${ }^{112}$ stands for the proposition that one cannot lawfully mount a spring-loaded shotgun in one's unoccupied building to harm trespassers who intrude during one's absence. One cannot be permitted to destroy another's life or health, even in defense of one's property.

In a foil to Wisconsin's decision in Jacque, the New Jersey Supreme Court in State v. Shack ${ }^{113}$ declined to enforce a criminal trespass provision against two men, Tejeras and Shack, who entered a farm without the farmer's permission for the purpose of providing medical and legal services to migrant workers who were residing there. ${ }^{114}$ The text of the statute clearly prohibited any trespass by one who was forbidden to enter by the owner of the land. ${ }^{115}$ It did not foreclose the argument that Tejeras and Shack might be considered invitees of the migrant workers, and therefore not trespassers. The case could have been disposed of rather uncontroversially on that ground. But rather than take that obvious way out, the court drilled all the way down to first principles and built an argument against impregnable owner sovereignty.

The court began its analysis with the declamation, "Property rights serve human values." 116 This fact the court considered both the source of, and a limitation upon, property rights themselves. The court stated, "[a] man's right in his real property of course is not absolute." 117 The maxim that one should use his property so as not to injure others expresses the "inevitable proposition that rights are relative and there

\footnotetext{
${ }^{110} I d$. at 959-63.

${ }^{111}$ Use your own property so as not to injure your neighbors. State v. Shack, 277 A.2d 369, 373 (N.J. 1971).

112 Katko v. Briney, 183 N.W.2d 657 (Iowa 1971).

113 Shack, 277 A.2d 369.

${ }^{114} I d$. at 370 .

115 Id.

$116 I d$. at 372 .

117 Id. at 373.
} 
must be an accommodation when they meet." 118 The court ruled that there had been no trespass because, the farmer's owner sovereignty did all of the accommodating.

The court did not clearly indicate what it meant by its reference to human values. But one can speculate based upon the facts of the case. That Tejeras and Shack entered the farm to provide medical and legal services suggests that they intended to serve the health of the migrant workers there, and to protect their rights. Health is of course an aspect of the basic good of life. Justice is entailed in the requirements of practical reasonableness. ${ }^{119}$ Owner sovereignty therefore gives way when it is used to threaten human goods.

This principle appears throughout property law, particularly the law of land use. State laws contain and authorize numerous types of restrictions and controls on owner sovereignty. But perhaps the most dramatic is the zoning ordinance. Zoning ordinances anticipate property disputes ex ante, and coercively regulate and restrict many aspects of land use for the purpose of coordinating the action of landowners. Indeed, zoning ordinances attempt to forfend some actions that are unlikely even to give rise to private disputes, such as the aesthetic appearance of structures and energy conservation. ${ }^{120}$

\footnotetext{
118 Id.

119 Finnis, Natural Law And Natural Rights, supra note 25, at chs. 7 \& 8.

120 See, e.g., Colo. REv. STAT. §§ 30-28-111(1), -115(1) (West 2011):
}

The county planning commission of any county may, and upon order by the board of county commissioners in any county having a county planning commission shall, make a zoning plan for zoning all or any part of the unincorporated territory within such county .... Such regulations shall be designed and enacted for the purpose of promoting the health, safety, morals, convenience, order, prosperity, or welfare of the present and future inhabitants of the state, including lessening the congestion in the streets or roads or reducing the waste of excessive amounts of roads, promoting energy conservation, securing safety from fire, floodwaters, and other dangers, providing adequate light and air, classifying land uses and distributing land development and utilization, protecting the tax base, securing economy in governmental expenditures, fostering the state's agricultural and other industries, and protecting both urban and non-urban development. 
Every state authorizes its municipalities to enact zoning ordinances. ${ }^{121}$ Following the now-canonical formulation from Village of Euclid, Ohio v. Ambler Realty Company ${ }_{1}^{122}$ state zoning enabling statutes generally authorize land use regulations to promote the public health, safety, and general welfare ${ }^{123}$ and, in many states, morals. ${ }^{124}$ These state interests are understood to be non-arbitrary, so they must have some foundation in rational values. It is beyond the province of this article to explore what the connection might be. ${ }^{125}$ It is sufficient to note that property uses

121 Ala. Code $\S \S 11-52-70,-72$ (2011); Alaska STAT. $§ \S 29.40 .030, .040$ (2011); ARIZ. Rev. Stat. § 9-462.01 (2011); ARK. Code Ann. § 14-56-403 (2010); Cal. Gov't Code § 65850 (West 2011); Colo. Rev. STAt. \$§ 30-28-111(1), -115 (2010); ConN. Gen. Stat. § 8-2 (2010); Del. Code AnN. tit. 22, § 301 (2010); Fla. Stat. § 163.3161 (2011); Ga. Code AnN. $\S \S 36-66-2,-5$ (2011); Haw. Rev. Stat. § 46-4(A)(5), (6) (2011); IdAho CodE AnN. §§ 676502, -6511 (2011); 65 Ill. COMP. STAT. 5/11-13-1; IND. CODE § 36-7-4-601 (2011); IOWA Code § 414.1(1) (2010); Kan. Stat. Ann. § 12-741(a) (2009); Ky. Rev. Stat. Ann. § 100.201(2) (West 2010); La. Rev. Stat. Ann. § 33:4721 (2011); Me. Rev. Stat. tit. 30, § 4352 (2011); MD. Code ANN. art. 23A, §§ 2(a), (b)(36)(i)-(ii) (2011); MASs. GEN. LAws Ch. 40A, § 5 (2010); Мich. Comp. Laws $§ 125.3201$ (2011); MinN. Stat. § 462.357 (2010); Miss. CodE Ann. § 17-1-3(1) (2010); Mo. Rev. Stat. § 65.662 (2011); Mont. Code AnN. § 76-2-301 (2010); Neb. Rev. Stat. § 14-401 (2010); Nev. Rev. Stat. AnN. § 278.020(1) (West 2010); N.H. Rev. Stat. AnN. § 674:16(i) (2010); N.J. Stat. AnN. §§ 40:55D-2, -62 (2011); N.M. Stat. AnN. § 3-21-1(A) (2010); N.Y. Gen. City LaW § 20(25) (McKinney 2011); N.C. GeN. Stat. § 160A-381 (2010); N.D. Cent. Code § 40-47-01 (2011); Ohio Rev. Code AnN. § 519.02 (West 2011); OKLA. STAT. tit. 11, § 43-101 (2010); OR. REV. STAT. § 227.090 (2009); 16 Pa. Cons. Stat. § 5220, 5226 (2010); R.I. Gen. Laws § 45-24-30(1) (2011); S.C. CodE ANN. §§ 6-29-710(A), -720 (2010); S.D. CODIFIED LAWs § 11-2-13 (2010); TENN. CoDE ANN. § 13-7-201 (2010); TeX. Loc. Gov’t Code AnN. \$ 211.001, 211.003 (West 2010); Utah Code Ann. § 10-9a-102(1), -501 (2011); Vt. Stat. AnN. tit. 24 § 4302 (2011); VA. CodE AnN. §§ 15.2-2280, -2283 (2011); WASH. REV. CODE $\$ 35.63 .080$ (2011); W. VA. CODE $\S 8$ AA-7-1, 8A3-1 (2011); Wis. STAT. § 59.69 (2010); WYO. STAT. ANN. § 15-1-601 (2011).

122 Vill. of Euclid Ohio v. Ambler Realty Co., 272 U.S. 365 (1926).

123 See, e.g., N.Y. GEN. City LAW § 20(25) (McKinney 2011):

Subject to the constitution and general laws of this state, every city is empowered . . . To regulate and restrict the location of trades and industries and the location of buildings, designed for specified uses, and for said purposes to divide the city into districts and to prescribe for each such district the trades and industries that shall be excluded or subjected to special regulation and the uses for which buildings may not be erected or altered. Such regulations shall be designed to promote the public health, safety and general welfare and shall be made with reasonable consideration, among other things, to the character of the district, its peculiar suitability for particular uses, the conservation of property values and the direction of building development, in accord with a well considered plan.

124 See, e.g., Del. CodE ANN. tit. 22, § 301 (2010):

For the purpose of promoting health, safety, morals or the general welfare of the community, the legislative body of cities and incorporated towns may regulate and restrict the height, number of stories and size of buildings and other structures, percentage of lot that may be occupied, the size of yards, courts and other open spaces, the density of population, and the location and use of buildings, structures and land for trade, industry, residence or other purposes.

${ }^{125}$ It seems plausible to suggest that many of these state interests correspond to the most basic goods of a community and its members, such as life and health. This idea makes it 
often implicate states' interests, that those state interests are understood to protect or promote intelligible goods, and that the state has the authority to restrict property owner sovereignty in order to promote or protect those goods.

That the ubiquitous use of zoning ordinances is uncontroversial suggests widespread agreement that property owners should not be permitted to use their assets in such a way as to jeopardize or harm certain community interests. And one would expect this limitation on autonomy to be uncontroversial because it is consistent with all of the reasoned, defensible accounts of autonomy described in Part II. Notably, that this limitation is uncontroversial suggests that Untrammeled Autonomy is untenable. If the basic goods are in fact common goods, and not merely individual goods, then exercising untrammeled autonomy is bound to harm someone and undermine that person's own autonomy.

\section{Charitable Tax Deductions}

\section{Lesson Three: Personal Autonomy Is an Important Condition of the Realization of Reflexive Basic Goods}

That the best discussions of the moral value of choice and autonomy address taxation policy is no accident. ${ }^{126}$ Taxation is an exercise of coercion that every citizen experiences and it presents a challenge to the idea that autonomy has value. That challenge is answerable, ${ }^{127}$ but this is not the place to explore the answers. Rather, one specific tax policy raises a particularly relevant concern. Many states, following the United States government, allow taxpayers to deduct from their reported income donations that they have made to a charity. ${ }^{128}$ The charity deduction might appear to run contrary to the lesson gleaned in the previous section. If states rightly act to protect and promote good ends by coercive means, why do states not simply confiscate those funds that taxpayers are currently donating to charity and direct them instead to the needs that the state has identified?

possible to speculate about the rational foundations of other aspects of land use law, particularly the law concerning judicial review of land use decisions. For example, one might observe that the most fundamental and significant interests on the basis of which municipalities often regulate land use are interests in the preservation and protection of basic human goods, such as health and life. One might then infer that those interests that qualify as compelling are those that directly implicate basic goods. For a very cursory exploration of this idea, see Adam J. MacLeod, A Non-Fatal Collision: Interpreting RLUIPA Where Religious Land Uses and Community Interests Meet, 42 URB. LAW. 41, 81-88 (2010).

${ }^{126}$ See OLREE, supra note 5, at 30, 211-14; RAZ, supra note 20, at 416.

127 Olree claims that people of good conscience, especially Christians, have a duty to pay their taxes, which does not correspond to duties to perform other acts that the government might coerce. OlREE, supra note 5, at 77-80, 212. Raz locates the obligation to pay taxes within the value of autonomy itself.

[I]f the government has a duty to promote the autonomy of people the harm principle allows it to use coercion both in order to stop people from actions which would diminish people's autonomy and in order to force them to take actions which are required to improve peoples' options and opportunities.

RAZ, supra note 20, at 416.

128 See, e.g., Ala. CODE $\$ 40-18-15(\mathrm{a})(10)(2011)$. 
One possible explanation is economic. Perhaps private charitable conduct is more efficient at meeting the needs of the disadvantaged than government redistribution. But in a number of areas both the national government and state governments have determined that this is not the case. For example, on the justification that private charity is ineffectual to provide adequate health care to the elderly and the poor, federal and state governments use coercive taxation to fund Medicare and Medicaid programs.

An alternative explanation for the charitable deduction is that charity has value. Charity might be understood as a basic good, or as an instantiation of the basic good of practical reasonableness. But in either case it seems uncontroversial to observe that charity is both objectively good and reflexive in nature. That is, charity is valuable in and of itself, but the value of charity depends upon it being freely chosen. To coerce someone to be generous does not make that person charitable, it simply separates that person from his or her money.

Charity, like all reflexive goods, must be internalized by the exercise of personal autonomy. The act of charity has a profound effect on the donor's identity; it makes the donor, to borrow from Finnis, "a different sort of person." 29 It makes a difference not only to the material condition of the recipient but also to the moral condition of the donor herself-her character. The donor realizes something of value by giving freely and internalizes this value into her identity, as she makes the well-being of the recipient a new reason for her own action.

The charitable act could not have this effect upon the charitable person if it were coerced. One who is required by law to part with her money for the material comfort of another is not making the material comfort of the other person a reason for her action. Instead, the coercion is the reason for her action. She might, if she is a naturally empathetic and caring person, nevertheless internalize care and concern for poor people generally. But she will not have established a moral connection with a particular recipient. Nor will she have created for herself a new reason to behave in a generous manner.

All of this seems quite consistent with the observations of Finnis and George about the reflexivity of some basic goods. And this has important implications for the autonomy wars described in the Introduction. Authoritative Paternalism occasionally overreaches because it fails to account for the reflexivity of some goods, such as charity and practical reasonableness. The stated objective of requiring citizens to undertake certain economic actions, such as purchasing health insurance and paying taxes to support social safety nets, is not merely to provide for the needs of others but also to make citizens more responsible. But the coercion used to achieve that end makes the end unachievable. When the government requires citizens to provide financial support for social programs it deprives them of the opportunity to choose. And if they cannot choose, then citizens do not make charity a reason for their future actions.

\section{Assisted Suicide}

\section{Lesson Four: Some Autonomous Acts Are Valueless}

When Montana became the third state to legalize assisting suicide, joining Washington and Oregon, it left Idaho as a regional outlier. In contrast to its

129 FinNis, Moral ABSOLUTES, supra note 21, at 20. 
neighbors, Idaho has not abolished the common law prohibition against the assistance of suicide. Instead, Idaho retains the common law, which treats assisting suicide as a crime. Is Idaho reasonable to hold out against the regional trend? If Idaho were simply to look around at its neighbors it might have cause to doubt its position.

Some claim that respect for personal autonomy places principled limits on the state's interest in preserving life. ${ }^{130}$ That is, the case for legalizing assisted suicide rests not merely, or even predominantly, on practical arguments about alleviating suffering; it is not a matter of contingent judgment about prudential considerations. Rather, as the argument goes, the moral case for prohibiting assisted suicide, which begins with a principle of respect for human life, is in conflict with a moral case for legalizing assisted suicide, which rests upon a principle of respect for personal autonomy. The only way to resolve the ostensible conflict between the value of life and the value of autonomy is to legalize self-harmful autonomous acts, such as receiving assistance in suicide. ${ }^{131}$

Thus one legalization proponent argues that each individual ought to be free to "lead a life that makes use of her distinctive abilities and satisfies her particular aspirations and desires." 132 The valuation of human life is a matter of subjective judgment about how fulfilling one's life actually is, and suicide is "an appropriate, though not obligatory, response when there is no further possibility of living a fulfilling life." ${ }^{133}$ In other words, any value in life is to be found only in the extrinsic ends that it serves. When those ends cease to be valuable, it is reasonable to destroy one's own life.

This assessment of the value of human life rests upon a conception of Untrammeled Autonomy, which takes self-made reasons to be the only reasons for

130 Jo Samanta, Lasting Powers of Attorney for Healthcare Under the Mental Capacity Act 2005: Enhanced Prospective Self-Determination For Future Incapacity or a Simulacrum?, 17 MED. L. REV. 377, 388-89 (2009).

131 The district court in Compassion in Dying v. Washington, 850 F. Supp. 1454 (W.D. Wash. 1994), began its search for a liberty interest by quoting the Casey mystery-of-life passage, then framed the "underlying constitutional issue" as whether the state "can resolve the profound spiritual and moral questions surrounding the end of life in so conclusive a fashion as to deny categorically any option for a terminally ill, mentally competent person to commit physician-assisted suicide." Id. at 1460. The court dismissed the notion that saving human life might justify burdening a right to suicide because "only one life is involved and that person can voice his or her wishes." Id.

Judge Reinhardt, who wrote the opinion for the en banc majority, also quoted the Casey mystery-of-life passage then went on, "[1]ike the decision of [sic] whether or not to have an abortion, the decision how and when to die is one of 'the most intimate and personal choices a person may make in a lifetime,' a choice 'central to personal dignity and autonomy."” See also Dying v. Washington, 79 F.3d 790, 813-14 (9th Cir. 1996) (quoting Planned Parenthood of Se. Pa. v. Casey, 505 U.S. 833, 851 (1992)).

132 Edward Rubin, Assisted Suicide, Morality, and Law: Why Prohibiting Assisted Suicide Violates the Establishment Clause, 63 VAND. L. REV. 763, 778 (2010).

133 Id. at 780. 
action. If autonomy is the supreme value then all other human goods, including human life, are contingent. There is no "uniform ethos," no "higher purposes,"134 no common goods. Human action should be directed only toward "self-defined goals that will provide the most subjectively satisfying life." 135

If this argument holds, and the value of human life is contingent, as a matter of subjective evaluation, then the moral case for legalizing assisted suicide deserves careful attention. But the judgments of state lawmakers reflect ambivalence, at most, about the principled case for respecting personal autonomy in the area of assisted suicide. A survey of state laws discloses a much more limited role for personal autonomy in this area. Only three states-Oregon, Washington, and Montana-have de-criminalized assisted suicide. The other forty-seven states maintain criminal penalties for the act. And though no state punishes the act of suicide itself, no state law expressly permits it.

Proponents of legalizing assisted suicide sometimes point out that states do not punish the act of suicide itself. ${ }^{136}$ But this fact cannot bear the weight that legalization proponents would place on it. In its landmark Glucksberg decision, the Supreme Court recognized that de-criminalization of suicide "did not represent an acceptance of suicide; rather, as [Connecticut] Chief Justice [Zephania] Swift observed, this change reflected the growing consensus that it was unfair to punish the suicide's family for his wrongdoing." 137 Justice Souter wrote separately to advocate for a liberty interest in assisted suicide. He nevertheless acknowledged that the state abolished punishments for suicide "largely because the common-law punishment of forfeiture was rejected as improperly penalizing an innocent family." 138

Further evidence that de-criminalization was primarily about the effects of punishment, and not about permitting or approving suicide, can be found in state case reports. Despite the inefficacy of punishing suicide, many states continue to identify volitional suicide as a crime ${ }^{139}$-an act that is "ethically reprehensible and inconsistent with the public welfare," 140 and "unlawful and criminal as malum in se." ${ }^{141}$ Less than 40 years ago the Supreme Court acknowledged constitutionally unchallenged prohibitions against suicide. ${ }^{142}$ As one state court explained, "[s]uicide

\footnotetext{
${ }^{134} I d$. at 778 .

135 Id.

136 See, e.g., OLREE, supra note 5, at 205.

137 Washington v. Glucksberg, 521 U.S. 702, 713 (1997).
}

${ }^{138} I d$. at 774. If anything, the abolition of criminal sanctions for suicide in the United States and Great Britain was accomplished, "not to help people commit suicide, but to help them not to." John Keown, The Legal Revolution: From 'Sanctity of Life' to 'Quality of Life' and 'Autonomy', 14 J. Contemp. Health L. \& Pol'y 253, 279 (1998). The general belief now prevails that a suicidal person needs help, not punishment. Id.

139 Thomas J. Marzen et al., Suicide: A Constitutional Right?, 24 DuQueSNE L. ReV. 1, 7982 (1985).

140 May v. Pennell, 64 A. 885, 886 (Me. 1906).

${ }^{141}$ Commonwealth v. Mink, 123 Mass. 422, 429 (1877).

142 Paris Adult Theater I v. Slaton, 413 U.S. 49, 68 n.15 (1973). 
is none the less criminal because no punishment can be inflicted. It may not be indictable because the dead cannot be indicted." 143

Not only criminal law but also state property law expresses disapprobation of volitional suicide. Indeed, autonomous suicidal acts actually earn greater disapproval in state property law than suicidal acts that are driven by depression or mental illness. A freely-chosen suicide cannot serve as the anticipated death that completes a gift causa mortis. ${ }^{144}$ This prohibition is justified on the ground that the courts should not honor a gift that was conditioned upon "the commission of a felony by the giver, and that felony [is] of the highest form." 145 The unenforceable gift is conditioned upon a "grave public wrong." 146 Enforcement would be inconsistent with states' "consistent views disfavoring suicide." 147

State budgetary priorities reflect disapprobation of suicide. Even the few states that have de-criminalized assisted suicide today invest resources in suicide prevention. Like many other states, Washington subsidizes crisis counseling services to dissuade suicidal acts. ${ }^{148}$ Counselors employed in that state apparently have the unenviable task of distinguishing between those suicidal decisions that are worthy of deference and those that are not.

State tort law also aims to discourage suicide. Most states recognize in law a privilege from tort liability for intervening in a suicide attempt. ${ }^{149}$ The privilege covers any interference in self-destruction or self-injury. Also, many states permit involuntary commitment of one who, due to a mental illness, is likely to harm himself. ${ }^{150}$ Significantly, these laws make no provision for subjective or utilitarian

${ }^{143}$ State v. Carney, 55 A. 44 (N.J. 1903). See also McMahan v. State, 53 So. 89, 90 (Ala. 1910); State v. Willis, 121 S.E.2d 854, 856 (N.C. 1961). "No sophistry is tolerated in consideration of legal problems which seek to justify self-destruction as commendable or even a matter of personal right.” Blackwood v. Jones, 149 So. 600, 601 (Fla. 1933).

144 Adam J. MacLeod, A Gift Worth Dying For?: Debating the Volitional Nature of Suicide in the Law of Personal Property, 45 IDAHO L. REV. 93 (2008), and the cases cited therein.

145 Agnew v. Belfast Banking Co., [1892] 2 I.R. 204, 213.

146 Bainbridge v. Hoes, 149 N.Y.S. 20, 22 (App. Div. 1914). See also In re Fanning, [1922] 3 D.L.R. 925, 926 (Can.); In re Dudman, [1925] Ch. 553-54 (Eng.).

147 In re Estate of Smith, 694 A.2d 1099, 1105 n.4 (Pa. Super. Ct. 1997) (Cirillo, J., dissenting).

148 See, e.g., Wash. State Univ. Counseling and Testing Services, http://counsel.wsu.edu/Default.asp (last viewed Oct. 15, 2011).

149 Neil M. Gorsuch, The Future of Assisted Suicide And Euthanasia 32 (2006); Marzen et al., supra note 139, at 148-242. New York's statute is illustrative.

The use of physical force upon another person which would otherwise constitute an offense is justifiable and not criminal under any of the following circumstances: . . . A person acting under a reasonable belief that another person is about to commit suicide or to inflict serious physical injury upon himself may use physical force upon such person to the extent that he reasonably believes it necessary to thwart such result.

N.Y. PENAL LAW $§ 35.10$ (McKinney 2009).

${ }^{150}$ Marzen et al., supra note 139, at 148-242. 
valuations of life. The person who interferes in the suicidal act is not required to weigh the instrumental value of the life saved, either to the suicidal person or to the community. This reflects the intrinsic, non-contingent value of human life. A suicide harms both the individual and the community simply because it causes the loss of a human life; the value of the life is neither subjective nor relative to other considerations.

So, forty-seven states prohibit assisted suicide. And the other three retain numerous legal provisions designed to discourage and even prevent suicide. Are all of these laws rational? Are there good reasons for states to limit the freedom of citizens to give and receive assistance in committing suicide? In short, yes. The most important of these reasons is what some philosophers call the inviolability-oflife principle. ${ }^{151}$ This principle has a long history in both philosophy and law. It has been recognized "in most, if not all, civilised [sic] societies throughout the modern world." ${ }^{152}$ And it is still reflected today in the provisions of state law just considered.

The inviolability-of-life principle holds that human life is a basic good. It is one of those goods that Raz, Dworkin, Finnis, and George all affirmed has intrinsic value; it is valuable in and of itself. It follows that, since human life is a reason for action in itself, one can and should refrain from "actions intended to do it harm.".153

The inviolability-of-life principle rules out assisted suicide and euthanasia, though it does not require that measures must always be taken to keep human beings alive. ${ }^{154}$ Sometimes one's reason for choosing life might be defeated by some other reason, but it can never be reasonable to intend to cause death, to have the destruction of life as one's purpose. So, for example, a fireman or a soldier who risks his own life to save another, knowing that his death might result, but not intending it, acts reasonably. Similarly, one who refuses a drastic and intrusive medical treatment that might (or might not) save one's life is not committing suicide. ${ }^{155}$ But one never has a reason deliberately to destroy innocent human life,

151 GoRsuch, supra note 149, at 167; John Keown \& David Jones, Surveying the Foundations of Medical Law: A Reassessment of Glanville Williams's The Sanctity of Life and the Criminal Law, 16 MED. L. REV. 85, 95-101, 118-24 (2008).

152 Keown \& Jones, supra note 151, at 95.

153 GoRsuch, supra note 149, at 164.

${ }^{154} I d$. at 218. Gorsuch observes, "[w]hile laws against assisted suicide plainly restrict some choice, consistent with the inviolability-of-life principle, they restrict only a limited arena of human actions-those intended to kill." Id. at 167 (emphasis in original). The inviolability-of-life principle does not entail that the government should prohibit or prosecute every act by which human life is foreseeably taken. The principle preserves "significant liberty to patient and doctor alike to discontinue or apply palliative treatment even in circumstances where death is foreseen as a certainty." Id. at 168. In these cases, and in other cases where death is a foreseeable but unintended, secondary consequence of reasonable actions, the state should not trample upon autonomous choices.

155 In these cases Finnis observes, “[o]ne's death is not chosen, for it is neither one's end, nor a means to one's end, but a side-effect, foreseen and accepted (but not intended, not chosen), of one's choice to reject the burden." John Finnis, The "Value of Human Life" and "The Right to Death": Some Reflections on Cruzan and Ronald Dworkin, 17 S. ILL. U. L.J. 559, 565 (1993). 
even one's own life. For the same reason, it can never be reasonable to assist another person in taking her own life. Thus, states reasonably prohibit assisted suicide.

That states treat human life as inviolable suggests an important limitation upon personal autonomy. Suicide consists of the deliberate destruction of a basic human good (life) for the realization of no other intelligible good. ${ }^{156}$ It is thus an irrational act. That suicide is performed autonomously does not render the act reasonable, say state lawmakers. Indeed, an autonomous suicide destroys autonomy itself. When a life ends, all of the exercises of personal autonomy that we recognize as valuable also come to an end. By its very operation the act of suicide assures that the actor will never again realize any valuable ends, including those goods that are reflexive in nature. ${ }^{157}$

\section{E. Compulsory Education Laws}

Lesson Five: Not All Basic Goods Appear to Be Reflexive

John Keown and David Jones have memorably explained the distinction between chosen death and death as a side effect. To claim that the heroism of personal sacrifice justifies suicide is to embrace the fallacy "that because heroes or martyrs foresee death, they therefore intend death." Keown \& Jones, supra note 151, at 118-19. On this mistaken view, "both Judas and Jesus were suicides.” Id. at 119.

156 Some claim that the destruction of human life performed to avoid extreme suffering does serve an intelligible end, namely the avoidance of suffering. See, e.g., PETER Singer, WRITINGS ON AN ETHICAL LIFE 194 (2000). However, avoidance of suffering is not intelligible as a reason for action, though it is certainly understandable as a sub-rational motivation. A moment's reflection reveals that avoiding some suffering actually causes harm, as where one refuses to go to the dentist to have a rotten tooth removed. Indeed, the realization of many good ends entails suffering. I cannot remain healthy without exercising, which is usually uncomfortable. I cannot establish a friendship without taking an interest in another person, which entails setting aside my own vanity and self-importance, disciplines that I, a particularly vain and self-important person, naturally experience as sacrifices.

On the other hand, suffering is not an intelligible end; one who chooses suffering for its own sake acts irrationally. Suffering and avoidance of suffering, then, are morally neutral. One cannot discern whether the sub-rational desire to avoid this or that particular instance of suffering is consistent with reason until one considers whether the suffering in this or that particular case will accrue to the sufferer's benefit or harm. In order to answer that question, one must look beyond suffering for intelligible reasons for action. And because a reason for action, such as human life, can never be defeated by a sub-rational motivation, such as the desire to avoid suffering, one's reason for choosing life can never be defeated by a desire to avoid pain or suffering.

157 For this reason, "assisted suicide does not enhance freedom." Scott FitzGibbon, The Failure of the Freedom-Based and Utilitarian Arguments for Assisted Suicide, 42 AM. J. JURIS. 211, 212 (1997). Rather, it "violates the subject's freedom because it puts an end to further activities and projects." $I d$. at 213. Furthermore, it "violates commitments he may have made" in the past, those reasons that he created for himself through the autonomous process of self-determination. $I d$. 
Every state requires children either to attend school or to obtain an equivalent education elsewhere. ${ }^{158}$ By requiring children and their parents affirmatively to pursue educational goals, these laws burden a liberty interest. ${ }^{159}$ The Supreme Court in 1925 held that a state compulsory education law, which required all children to attend public schools, unreasonably interfered with the liberty of parents and guardians to direct the upbringing and education of children in their custody. ${ }^{160}$ The Court reasoned,

[t]he fundamental theory of liberty upon which all governments in this Union repose excludes any general power of the state to standardize its children by forcing them to accept instruction from public teachers only. The child is not the mere creature of the state; those who nurture him and direct his destiny have the right, coupled with the high duty, to recognize and prepare him for additional obligations. ${ }^{161}$

Thus, as the Court later affirmed in Wisconsin v. Yoder ${ }^{162}$ parents retain the right to direct the manner and venues in which their children will be educated.

Nevertheless, this liberty interest does not free parents and children from the reach of state educational requirements altogether. The Court in Pierce noted that no question was raised about the power of states to regulate schools, to require that all children of proper age attend some school, and to require the teaching of "certain studies plainly essential to good citizenship." ${ }^{163}$ Coercion is permitted, within limits, and as a means to particular ends.

Yoder did not disturb this ruling. In Yoder, the Supreme Court famously held that Amish children could be exempted from compulsory education beyond the eighth grade. But the justification for this decision was not a general liberty interest but rather Free Exercise protection. ${ }^{164}$ The Amish claimants did not rest their claim upon personal autonomy or personal preferences. To the contrary, obedience to their religiously-informed consciences meant obedience to their community's doctrines. ${ }^{165}$

Also, the Court in Yoder took pains to affirm the rationality of compulsory education laws. "There is no doubt as to the power of a State," the Court declaimed, "having a high responsibility for education of its citizens, to impose reasonable

158 Mark G. Yudof et AL., Education Policy AND the Law 1 (4th ed. 2002); Rebecca Aviel, Compulsory Education and Substantive Due Process: Asserting Student Rights to a Safe and Healthy School Facility, 10 LewIS \& Clark L. REv. 201, 204 (2006); Notes, A Right to Learn?: Improving Educational Outcomes Through Substantive Due Process, 120 Harv. L. Rev. 1323, 1330 (2007) [hereinafter "Right to Learn”].

159 Right to Learn, supra note 158, at 1330-31.

${ }^{160}$ Pierce v. Soc'y of the Sisters of the Holy Names of Jesus and Mary, 268 U.S. 510, 53435 (1925).

161 Id. at 535.

162 Wisconsin v. Yoder, 406 U.S. 205 (1972).

163 Pierce, 268 U.S. at 534.

164 Yoder, 406 U.S. at 219.

165 Id. at 215-18. As the Court recognized, the Amish way of life "is not merely a matter of personal preference, but one of deep religious conviction, shared by an organized group, and intimately related to daily living." Id. at 216. 
regulations for the control and duration of basic education." ${ }^{166}$ The point, for present purposes, is not that the Court perceived the value of knowledge resting in its instrumental usefulness for producing good citizens. Rather, the point is that the value of knowledge was not destroyed by the compulsion directed toward its acquisition.

The rationality of compulsory education laws raises the possibility that coerced pursuit of at least one basic good has intelligible value. If compulsory education laws are reasonable then there must be some conclusive reason or reasons for them. If knowledge is not a basic good, or if it is reflexive and its value is contingent on its being freely chosen for the right reasons, there exists no intelligible reason to force children to acquire it, or to force children's parents to comply with the acquisition.

Similarly, unless aesthetic experience has intelligible value even when coerced there would be no reason to require children to sit through music and art classes. Unless health has intelligible value when coerced there would be no reason to compel physical education. But of course knowledge, aesthetic experience, and health do provide intelligible reasons for such laws. That every state has some form of compulsory education law illustrates that rational minds grasp the value of these coercive measures.

A principle of Untrammeled Autonomy should entail that compulsory education laws are unjust. As Finnis has observed, the principle articulated in Casey should entail that "since parents have a constitutionally protected right to provide non-State education for their children if they so choose, they must equally have the right to decide to give their children no education." 167

And the claim that autonomy is intrinsically valuable should entail that compulsory education laws are irrational. To observe that children are different than adults does not by itself resolve the problem. Some relevant difference between children and adults might be a reason for not coercing adults to attend school, but it cannot justify coercing children to attend school. To require the child's attendance is to override the autonomy of either the child or the parent, or both. That cannot be justified except on consequentialist grounds, which is another way of saying that it cannot be justified.

Alternatively, one might argue that children are not capable of exercising autonomy because they do not create life plans the way that adults do. ${ }^{168}$ Or perhaps they have a very limited capacity for autonomy because they do not make their own reasons for action as adults do, or they do so imperfectly. ${ }^{169}$ Thus the state might rationally coerce children to acquire knowledge without threatening children's autonomy. But just as this line of argument resolves one difficulty it raises other problems. Children realize basic goods other than autonomy, such as life, health, and knowledge. If autonomy is a basic good then one will expect it to be good for children as it is for adults, just as the other basic goods are good for children. If children lack the capacity for autonomy but enjoy the capacity to realize other basic

\footnotetext{
${ }^{166} I d$. at 213 .

167 Finnis, supra note 155, at 562.

168 Someone like Peter Singer might take this view. See generally, SINGER, supra note 156; Peter Singer, Taking Life: The Embryo and the Fetus, PRACTICAL Ethics 171 (Cambridge Univ. Press, 2d ed. 1993).

169 Joseph Raz might defend this view. See, e.g., RAZ, supra note 20, at 416.
} 
goods, that fact would cast doubt upon the idea that autonomy is in fact equally as basic as other goods.

More fundamentally, someone is exercising an autonomy interest in directing a child's education. If not the child, then a parent or guardian must have the capacity and freedom to choose how the child will be educated. But state law does not respect the autonomy of parents to decide whether the child will be educated. The law recognizes a liberty interest in parents to choose the manner and method of instruction, but that liberty interest does not include a right to leave the child in ignorance.

It thus appears that the realization of some basic goods-at least knowledge, aesthetic experience, and health — can rationally be coerced. At least all fifty states and the United States Supreme Court think so. Therefore the value of some goods does not depend in any way on the exercise of personal autonomy. This assessment appears to meet widespread acceptance among lawmakers.

\section{F. Legalized Marijuana Use}

Lesson Six: Neither a Principle of Personal Autonomy nor the Unconditional Value of Some Basic Goods Conclusively Resolves Every Controversial Legal Issue

Several states have recently decriminalized simple possession and use of marijuana. ${ }^{170}$ This policy decision implicates both autonomy and the protection of other goods, such as health and practical reasonableness. But unlike the areas of state law considered above, the controversy in this corner does not admit an obvious answer. It is instructive to examine why not.

The argument for criminalization proceeds from the observation that recreational marijuana use injures a basic human good, namely health, in service of no other rational end. (The pleasure that the user experiences is a sub-rational motivation, not a reason for using.) Furthermore, many marijuana users become addicted to marijuana and more destructive substances. These addictions often injure the user's relationships with other people, causing harm to the basic good of community. Health and community are non-reflexive basic goods; they retain their intelligible value even when they are not freely chosen. To deter injury to these goods, the state reasonably prohibits marijuana use and possession.

But this case can easily be overstated. Some chemical substances have greater deleterious effects than others. Alcohol is more or less destructive than marijuana, and both are arguably less destructive than heroin. And states permit the consumption of alcohol, in moderation and with certain restrictions, so why not marijuana? Once we frankly acknowledge that we are engaged in line drawing, how do we avoid being arbitrary about it?

The argument for legalization proceeds from the observation that criminalization will also harm the drug user in an important way, by deflecting the user from

170 See, e.g., AlASKa STAT. $\$ \S 17.37 .010$ to .080 (2011). According to one organization that keeps track, fifteen states have now legalized some uses of marijuana, and twelve additional states have pending legislation on the subject. 16 Legal Medical Marijuana States and D.C., ProCon.org, http://medicalmarijuana.procon.org/view.resource.php?resourceID=000881 (last visited Oct. 15, 2011); 6 States with Pending Legislation to Legalize Medical Marijuana, ProCon.org, http://medicalmarijuana.procon.org/view.resource.php?resourceID=002481 (last visited Oct. $15,2011)$. 
realizing the goods of autonomy and practical reasonableness. One does not act freely or uprightly when one chooses to avoid drug abuse only out of fear of punishment. However, it is easy to overstate this case, as well. It is particularly easy to underestimate the harm to users and their friends and family that results from much use and abuse of narcotics.

Moreover, legalization itself might deflect some marijuana users from exercising practical reasonableness, particularly those who are prone to abuse the drug. George observes that prohibiting harmful acts protects both the potential victims of harm and the immoral actors themselves. "For, by deterring such acts, the law may prevent people from habituating themselves to corrupting vices which will more or less gradually erode their character and will to resist." 171 Drug addiction, of course, is the paradigmatic instance of habituation to a corrupting vice, which erodes the character and will of the user.

So it might reasonably be argued that the degree of harm from either criminalization or legalization is less than immediately clear. Even when confined to moral considerations, this is a complicated issue. It becomes even more complicated once one includes prudential considerations. Will legalization or criminalization more dramatically incentivize a criminal black market in narcotics? Does criminalization actually deter potential users? Does it deter addicts? These questions admit of empirical answers, but that does not make them easy questions to resolve.

\section{CONCLUSION}

What can be said about personal autonomy then? State lawmakers by and large reject both Untrammeled Autonomy and Authoritative Paternalism. With Raz, Finnis, George, and Dworkin, and against the Untrammeled Autonomists, they affirm that the value of autonomy is limited, and that one cannot make an unreasonable act reasonable simply by choosing it. With Raz, Finnis, George, and Dworkin, and against the Authoritative Paternalists, they also affirm that personal autonomy is an important condition of human flourishing because it enables people to make pre-moral choices and to realize reflexive basic goods.

More can be said. State lawmakers apparently believe personal autonomy to be an important principle with moral implications. But they recognize important limitations upon the reach of that principle. Personal autonomy is reasonably curtailed when exercised to cause harm. Though it must be protected to enable people space to make pre-moral choices, and to realize reflexive basic goods, it need not be respected in all cases. The value of at least one basic good-human lifecannot reasonably be reduced to mere instrumentality for the sake of respecting personal autonomy. And autonomy adds nothing of value to an irrational act, such as suicide. Some goods-knowledge, aesthetic experience, and health-are reasonably realized through coercive means.

So some clear principles emerge. But there remains significant room for reasonable disagreement about the role and limitations of personal autonomy in areas of public policy where these clear principles are not in play. The law need not prohibit every harmful or irresponsible act. And there are good reasons to believe that it should not do so. Therefore lawmakers who seek to do good with intellectual

171 GeORGE, supra note 22, at 227. 
humility will recognize that many questions are not easily resolved simply by invoking or rejecting a principle of personal autonomy. 